\title{
Uji toksisitas fraksi aktif ekstrak etanol daun ginje (Thevetia peruviana) dengan metode Brine Shrimp Test dan profil kandungan kimia fraksi teraktif
}

\author{
Toxicity test of active fraction from ethanol extract of ginje (Thevetia peruviana) leaves by Brine \\ Shrimp Test method and chemistry compound profile of most active fraction
}

\author{
VIANA NINGSIH, ESTU RETNANINGTYAS NUGRAHENI, OKID PARAMA ASTIRIN \\ Jurusan Biologi, Fakultas Matematika dan Ilmu Pengetahuan Alam, Universitas Sebelas Maret. Jl. Ir. Sutami 36A Surakarta 57126, Jawa Tengah
}

Manuskrip diterima: 4 April 2013. Revisi disetujui: 31 Juli 2013.

\begin{abstract}
Ningsih V, Nugraheni ER, Astirin OP. 2013. Toxicity test of active fraction from ethanol extract of ginje (Thevetia peruviana) leaves by Brine Shrimp Test method and chemistry compound profile of most active fraction. Biofarmasi 11: 48-57. Cancer is a major threat to human health. The treatment that been made such as dissection, radiation, and chemotherapy, did not give satisfactory results, even gave the considerable adverse side effects. Other alternative that selected is utilizing the natural materials from plant that expected to be companion chemotherapy. One of the plants as source of new drug potentially is ginje (Thevetia peruviana Merr). Previous studies reported that ethanol extract of ginje leaves have toxic effects below $1000 \mu \mathrm{g} / \mathrm{mL}$. Therefore, it needs to be tested further to determine its potential as anticancer. This study aimed to determine the toxic effects of the active fractions of ethanol extract of ginje leaves by Brine Shrimp Test (BST) method and to determine the profile of active fraction of chemical constituents. Toxicity test was performed with Brine Shrimp Test (BST) method against Artemia salina Leach. Shrimp larva with a series concentrations extract of $62.5 \mu \mathrm{g} / \mathrm{mL}$, $125 \mu \mathrm{g} / \mathrm{mL}, 250 \mu \mathrm{g} / \mathrm{mL}, 500 \mu \mathrm{g} / \mathrm{mL}$ and $1000 \mu \mathrm{g} / \mathrm{mL}$ of each concentration were tested in 5 flacons. Each flacon contained 10 shrimp larva. The percentage of shrimp larva mortality was calculated after 24 hours of test and the data were analyzed by calculating the value of $\mathrm{LC}_{50}$. The profile of the chemical contents of the most active fraction were identified by TLC and analyzed qualitatively. The results showed that the most active fraction in killing the larva of shrimp Artemia is the fraction I with the values of $\mathrm{LC}_{50}-24$ hours was 44.67 $\mu \mathrm{g} / \mathrm{mL}$. The contents of chemical compounds contained in fraction I of leaf ethanol extract of ginje were terpenoid and phenolic groups.
\end{abstract}

Keywords: Brine Shrimp Test (BST), LC ${ }_{50}$, Thevetia peruviana, TLC, toxicity

\section{PENDAHULUAN}

Penyakit kanker merupakan salah satu ancaman utama bagi kesehatan manusia, karena merupakan penyebab kematian kedua setelah penyakit jantung (Fitria dan Lenny 2009). Penanganan kanker pada umumnya dilakukan melalui proses pembedahan, radiasi, dan kemoterapi (Harwoko dan Utami 2011). Namun hingga saat ini, hasil yang diperoleh belum memuaskan, bahkan memberikan efek samping yang merugikan karena selektivitasnya masih rendah (Setyowati et al. 2007). Alternatif lain yang dipilih oleh sebagian penderita kanker diantaranya adalah dengan memanfaatkan bahan alam dari tumbuh-tumbuhan sebagai obat alternatif (Sukardiman et al. 2004). Kelebihan dari pengobatan dengan tanaman obat secara tradisional adalah efek sampingnya lebih kecil jika dibanding dengan pengobatan secara kimiawi (Thomas 1986).

Indonesia memiliki kurang lebih 30.000 jenis tumbuhan dan baru sekitar 7000 jenis yang telah diketahui sebagai tumbuhan berkhasiat obat (Sari 2006). Dengan demikian, upaya pencarian sumber obat baru dari tumbuh-tumbuhan sangat penting dilakukan.

Ginje (Thevetia peruviana Merr.), anggota famili Apocynaceae, merupakan salah satu jenis tanaman yang berpotensi sebagai sumber obat baru. Tanaman ini biasa tumbuh di halaman rumah atau di pinggir-pinggir jalan sebagai tanaman hias (Mollah dan Islam 2007). Tanaman ini cukup melimpah, namun karena potensi dan khasiatnya belum banyak diketahui oleh masyarakat maka keberadaannya kurang diperhatikan. Ekstrak metanol daun T. peruviana mengandung alkaloid, saponin, flavonoid, glikosida, minyak, tanin, dan fenol, dan tidak mengandung karbohidrat, protein, dan asam amino (Kumar et al. 2011). Senyawa alkaloid dan flavonoid berpotensi sebagai antikanker (Aryanti et al. 2005).

Semua bagian tanaman $T$. peruviana bersifat toksik, terutama getah dan minyak bijinya (Langford dan Boor 1996). Namun, pembuktian terhadap toksisitas tanaman ginje masih belum banyak dilakukan (Roberts et al. 2005). Uji sitotoksik dengan metode Brine Shrimp Test (BST) dapat digunakan untuk menemukan senyawa antikanker baru (Harborne 1987). Metode ini merupakan uji pendahuluan dengan menggunakan larva udang Artemia salina Leach sebagai hewan uji. Elhardallou (2011) menyatakan bahwa hasil uji toksisitas dengan metode BST terbukti memiliki korelasi positif dengan aktivitas antikanker pada manusia. Selain itu, metode ini juga mudah dikerjakan, murah, cepat, dan cukup akurat (Meyer 
et al. 1982). Obat antikanker yang telah berhasil dikembangkan dari senyawa sitotoksik antara lain vincristine dan vinblastine yang berhasil diisolasi dari tanaman Catharanthus roseus, anggota famili Apocynaceae (Elhardallou 2011).

Pada penelitian Hasan et al. (2011) dilaporkan bahwa ekstrak etanol daun $T$. peruviana memiliki efek toksik terhadap larva udang $A$. salina dengan nilai $\mathrm{LC}_{50}$ sebesar 672,21 $\mu \mathrm{g} / \mathrm{mL}$. Menurut Meyer et al. (1982), suatu ekstrak dikatakan toksik pada uji BST jika nilai LC $_{50}<1000$ $\mu \mathrm{g} / \mathrm{mL}$. Pada nilai $\mathrm{LC}_{50}$ tersebut, suatu ekstrak dapat dikembangkan menjadi obat kanker, sehingga diperlukan penelitian lebih lanjut untuk menguji potensinya. Dalam penelitian ini dilakukan proses fraksinasi untuk mengetahui kandungan senyawa aktif yang berperan dalam memberikan efek sitotoksisitas. Diharapkan penelitian ini dapat memberikan informasi mengenai potensi tanaman $T$. peruviana sebagai kandidat antikanker.

Tujuan penelitian ini adalah untuk mengetahui efek toksik dari fraksi aktif ekstrak etanol daun ginje ( $T$. peruviana) dengan metode Brine Shrimp Test (BST) dan mengetahui profil kandungan kimia fraksi teraktif ekstrak etanol daun ginje.

\section{BAHAN DAN METODE}

\section{Waktu dan tempat penelitian}

Penelitian ini dilakukan pada bulan Januari-Mei 2012 di Laboratorium Biologi dan Laboratorium Pusat SubLaboratorium Biologi, Fakultas Matematika dan Ilmu Pengetahuan alam, Universitas Sebelas Maret, Surakarta.

\section{Bahan dan alat}

Bahan yang digunakan dalam penelitian ini adalah daun ginje (T. peruviana), etanol $70 \%$, etil asetat, kloroform, metanol, pereaksi semprot Serium (IV) sulfat, Dragendorff, Liebermann-Burchard, dan $\mathrm{FeCl}_{3}$, telur A. salina Leach, garam laut, akuades, suspensi ragi (Fermipan $\left.{ }^{\circledR}\right)$, CMC 0,1\%, dan silika gel GF254.

Alat yang digunakan adalah rotary evaporator, oven, lampu UV, kertas saring (Whatman 42), peralatan gelas, plat KLT silika gel GF254, botol penyemprot, aluminium foil, pipa kapiler, bejana pengembang, gelas arloji, mikropipet 10-1000 $\mu \mathrm{l}$, mikropipet 20-250 $\mu \mathrm{l}$, mikropipet 0,2-2 $\mu \mathrm{l}$, vortex, blender, neraca analitik, spatula, pipet tetes, flakon, kipas angin, aerator, sentrifuge, dan satu set peralatan KLTp (Kromatografi Lapis Tipis Preparatif).

\section{Cara kerja}

Persiapan sampel

Daun ginje segar sebanyak 1500 g dikumpulkan dari daerah Nogosari, Boyolali. Daun diambil pada ruas ke-10 hingga ruas ke-20 dari ujung daun. Tanaman ginje dideterminasi dan diidentifikasi di Laboratorium Biologi. Daun dicuci lalu dikeringkan di bawah sinar matahari secara tidak langsung dengan cara ditutup kain hitam, selanjutnya daun yang sudah kering dibuat serbuk dengan menggunakan blender.

\section{Ekstraksi}

Ekstraksi dilakukan secara maserasi dengan cara merendam serbuk daun ginje dengan etanol $70 \%$ hingga semua serbuk daun terendam selama 24 jam pada suhu ruang. Setelah 24 jam, ekstrak tersebut disaring dan ampasnya direndam kembali dalam etanol 70\% yang baru. Maserasi dan penyaringan dilakukan 3 kali. Masing-masing maserat yang telah disaring digabung dan diuapkan dengan rotary evaporator pada suhu $70^{\circ} \mathrm{C}$ hingga diperoleh ekstrak kental berwarna hijau kehitaman, lalu ekstrak tersebut disimpan dalam eksikator untuk menghindari kontaminan dari luar.

\section{Pencarian eluen terbaik}

Pencarian eluen terbaik dilakukan dengan KLT. Plat KLT ukuran $1 \mathrm{~cm}$ x $10 \mathrm{~cm}$ disiapkan kemudian diberi tanda batas $1 \mathrm{~cm}$ dari bawah dan $1 \mathrm{~cm}$ dari atas dengan pencil, sehingga jarak pengembangan $8 \mathrm{~cm}$. Sampel kemudian ditotolkan dengan pipa kapiler tepat di tengah-tengah garis bawah yang telah dibuat, setelah itu dibiarkan hingga kering. Kemudian sampel dimasukkan ke dalam chamber yang telah diisi dengan eluen. Eluen yang digunakan antara lain kloroform 100\%, kloroform:metanol (9,5:0,5) dan (9:1) (Sriwahyuni 2010), kloroform: metanol (8:2) (Sriwahyuni 2010), kloroform: etil asetat: metanol (2:1:1), serta kloroform:etil asetat (3:1) dan (2:1).

\section{Partisi}

Mula-mula ekstrak etanol daun ginje dimasukkan ke dalam Eppendorf dan ditambah dengan pelarut secukupnya lalu dilakukan sentrifugasi dengan alat sentrifuge pada kecepatan 2000 rpm selama 10 menit, sehingga diperoleh bagian yang larut dan bagian yang tidak larut dalam pelarut. Jenis pelarut yang digunakan untuk partisi ditentukan dengan dilakukan uji pendahuluan terlebih dahulu dengan KLT untuk melihat pemisahan yang optimal. Jika spot yang terbentuk antara bagian yang larut dan bagian yang tidak larut tidak tumpang tindih maka pelarut tersebut digunakan untuk proses partisi lebih lanjut. Kedua bagian yang diperoleh kemudian diuapkan hingga kental dan tidak berbau pelarut lagi, lalu ekstrak dilakukan uji toksisitas dengan metode BST. Fraksi yang lebih aktif selanjutnya difraksinasi dengan KLT preparatif.

\section{Fraksinasi dengan KLT preparatif}

Persiapan plat KLTp. Satu set alat pembuatan plat kaca KLTp disiapkan, kemudian silika gel GF254 ditimbang kurang lebih sebanyak 15 gram untuk mendapatkan 2 plat kaca, lalu ditambah dengan akuades secukupnya (1:2) dan diaduk hingga rata. Kemudian silika tersebut dituang dalam cetakan lalu didorong hingga terbentuk plat kaca yang diinginkan. Diusahakan permukaan silika rata. Kemudian plat kaca dimasukkan ke dalam oven pada suhu $50^{\circ} \mathrm{C}$ kurang lebih selama 15 menit lalu dikeringanginkan kembali.

Sampel yang sudah disiapkan kemudian ditotolkan pada plat kaca KLTp dengan jarak $1 \mathrm{~cm}$ dari bawah dibuat memanjang seperti pita sepanjang plat kaca $(20 \mathrm{~cm})$. Penotolan diulang kurang lebih 3 kali, kemudian plat kaca dikeringkan lalu dimasukkan ke dalam chamber dan dielusi 
dengan fase gerak yang sesuai. Jarak pengembangan adalah $8 \mathrm{~cm}$.

Pemisahan dilakukan dengan melihat hasil pengembangan di bawah UV. Pada paparan UV akan terbentuk noda-noda dengan pola tertentu. Noda yang terbentuk dengan nilai Rf yang sama ditandai lalu dikerok dan dikumpulkan menjadi satu fraksi.

Masing-masing fraksi yang diperoleh kemudian dimonitor profil kandungan kimianya dengan KLT. Berdasarkan hasil KLT, fraksi-fraksi dengan profil kromatogram yang hampir sama dijadikan satu. Fraksi hasil penggabungan tersebut selanjutnya diuji toksisitasnya dengan metode BST untuk mengetahui fraksi yang paling aktif.

\section{Uji toksisitas dengan metode BST}

Mula-mula dibuat larutan stok dengan cara melarutkan $500 \mathrm{mg}$ sampel dalam $50 \mathrm{ml}$ pelarut, sehingga diperoleh larutan stok dengan konsentrasi $10.000 \mu \mathrm{g} / \mathrm{mL}$. Pelarut yang digunakan disesuaikan dengan sifat kelarutan sampel. Konsentrasi yang digunakan dalam uji toksisitas adalah 62,5; 125; 250; 500; dan $1000 \mu \mathrm{g} / \mathrm{mL}$ (Hasan et al. 2011). Larutan diambil dengan menggunakan mikropipet dan dimasukkan ke dalam flakon. Kemudian flakon yang telah diisi dengan sampel diangin-anginkan hingga pelarut menguap dan tidak berbau pelarut lagi.

Telur A. salina ditetaskan dalam wadah yang telah berisi air laut pada kadar 3,8\% (3,8 g garam laut dalam 100 ml akuades) dan diaerasi dengan aerator. Telur akan menetas setelah kira-kira 24 jam menjadi larva. Larva yang berumur 48 jam dapat digunakan untuk uji toksisitas (Maridass 2008).

Flakon yang telah diisi dengan sampel yang sudah diuapkan pelarutnya kemudian ditambahkan dengan CMC 0,1\% $100 \mu \mathrm{l}$, kemudian ditambah dengan $2 \mathrm{ml}$ air laut dan 1 tetes ragi fermipan ( $3 \mathrm{mg} / 5 \mathrm{ml}$ ). Kontrol uji dibuat dengan memasukkan CMC 0,1\% sebanyak $100 \mu \mathrm{l}$ dan ditambah dengan air laut dan ragi fermipan 1 tetes tanpa penambahan ekstrak. Kemudian flakon-flakon tersebut divortex kurang lebih selama 1 menit agar semua bahan tercampur rata. Lalu dimasukkan sebanyak 10 ekor larva $A$. salina umur 48 jam. Setelah 24 jam dihitung jumlah larva A. salina yang mati (tidak bergerak) kemudian dicari nilai $\mathrm{LC}_{50}$-nya.

\section{Penentuan golongan senyawa fraksi teraktif}

Penentuan golongan senyawa fraksi teraktif dilakukan dengan kromatografi lapis tipis. Hasilnya dideteksi dengan sinar $U^{254} \mathrm{~nm}$ dan $\mathrm{UV}_{366} \mathrm{~nm}$ serta beberapa deteksi semprot penampak bercak yang meliputi serium (IV) sulfat, Lieberman-Burchad, Dragendorff, dan $\mathrm{FeCl}_{3}$. Setelah dilakukan penyemprotan, plat dipanaskan dalam oven pada suhu $110^{\circ} \mathrm{C}$ selama $10-15$ menit. Kemudian dilakukan penghitungan Rf.

\section{Analisis data}

Uji toksisitas dianalisis dengan menghitung jumlah $A$. salina yang mati setelah 24 jam perlakuan dengan rumus:

\section{$\%$ Kematian $=$ jumlah larva $A$. salina mati $\times 100 \%$ Jumlah larva uji}

Apabila terjadi kematian pada kontrol maka dapat dikoreksi dengan rumus Abbot's yaitu:

$$
\% \text { Kematian }=\frac{\text { jumlah larva } A . \text { salina (Mati-kontrol) }}{\text { Jumlah larva uji }} \times 100 \%
$$

Dari hasil tersebut selanjutnya dihitung nilai $\mathrm{LC}_{50}$ dengan mengubah persentase kematian menjadi nilai probit lalu dibuat kurva hubungan antara log konsentrasi dengan nilai probit dengan bantuan Ms. Excel, sehingga diperoleh persamaan garis liniernya.

Penentuan golongan fraksi teraktif dideteksi dengan kromatografi lapis tipis dengan fase gerak yang sesuai dan dideteksi dengan pereaksi semprot yang spesifik. Profil kromatografi lapis tipis hasil deteksi semprot spesifik dianalisis secara kualitatif.

\section{HASIL DAN PEMBAHASAN}

\section{Penyiapan bahan}

Bahan utama berupa daun ginje segar diambil di daerah Nogosari, Boyolali sebanyak 1.500 g. Sebelumnya, sampel dideterminasi untuk menghindari kesalahan dalam penggunaan sampel. Bahan yang diperoleh selanjutnya dicuci dengan air mengalir untuk menghilangkan debu/kotoran yang menempel pada daun supaya tidak ikut terekstrak. Setelah itu, daun dikeringkan dengan cara dijemur di bawah sinar matahari secara tidak langsung dengan ditutup kain hitam. Hal ini bertujuan agar kandungan senyawa di dalam daun tidak rusak akibat paparan radiasi sinar UV yang terlalu tinggi. Pengeringan bahan bertujuan untuk mengurangi kadar air dan menghentikan reaksi enzimatik, sehingga dapat mencegah kerusakan bahan. Selain itu, penggunakan bahan dalam bentuk kering dapat memudahkan masuknya larutan pengekstrak ke dalam sel dan menarik zat aktif yang terkandung di dalamnya secara sempurna (Djajanegara dan Wahyudi 2009) dan menghasilkan ekstrak yang lebih banyak jika dibanding dengan bahan yang masih segar (Cuellar et al. 2010). Daun yang sudah kering (simplisia) sangat mudah patah, berwarna hijau kecokelatan dan, setelah ditimbang diperoleh berat kering sebanyak 513,9 g.

Simplisia diblender hingga berbentuk serbuk (500 g). Pembuatan sediaan serbuk tersebut dimaksudkan untuk memperluas permukaan daun, sehingga ketika berinteraksi dengan pelarut, penetrasi pelarut ke dalam struktur seluler dari jaringan tanaman berlangsung lebih efektif. Hal ini akan mempermudah larutnya metabolit sekunder yang terkandung di dalam daun (Cannell 1998).

\section{Ekstraksi}

Ekstraksi dilakukan dengan metode maserasi atau perendaman. Metode maserasi dipilih karena metode tersebut lebih sederhana, mudah dikerjakan, dan biaya yang 
diperlukan relatif murah (Djajanegara dan Wahyudi 2009). Maserasi dilakukan dengan merendam serbuk daun ginje sebanyak $500 \mathrm{~g}$ dengan pelarut etanol 70\% ( $\pm 2,5$ liter $)$ selama 24 jam. Etanol 70\% digunakan sebagai pelarut karena mengikuti penelitian sebelumnya oleh Hasan et al. (2011) dan dikarenakan etanol merupakan senyawa polar, dimana berdasarkan sifat like dissolve like, pelarut polar akan melarutkan senyawa polar dan pelarut non-polar akan melarutkan senyawa non-polar. Senyawa yang diduga berperan dalam memberikan efek toksik dalam penelitian ini adalah senyawa polar. Etanol 70\% dianggap lebih optimal dibanding etanol $96 \%$ dalam proses penyarian. Hal ini dikarenakan etanol 70\% lebih banyak mengandung air, sehingga proses ekstraksi juga lebih optimal (Djajanegara dan Wahyudi 2009). Selama proses ekstraksi, pelarut akan berdifusi ke dalam sel tanaman dan melarutkan senyawa yang sama polaritasnya (Prashant et al. 2011). Apabila telah terjadi keseimbangan antara konsentrasi di dalam dan di luar sel maka proses ekstraksi akan terhenti. Daftar beberapa pelarut beserta komponen aktif yang dilarutkan ditunjukkan pada Tabel 1.

Maserasi dilakukan sebanyak 3 kali dengan pelarut baru. Hal ini bertujuan agar kandungan senyawa di dalam daun dapat tersari dengan optimal. Proses maserasi disertai juga dengan pengadukan agar terjadi interaksi yang merata antara cairan penyari dengan seluruh permukaan masingmasing serbuk. Selain itu menurut Cannell (1998), pengadukan bertujuan untuk meningkatkan efisiensi metode maserasi supaya kejenuhan pelarut terjadi lebih cepat dan maserat yang diperoleh lebih homogen. Kejenuhan terjadi apabila tidak ada perbedaan konsentrasi.

Penyaringan dilakukan sebanyak dua kali, yaitu tahap pertama dengan menggunakan kain dan tahap kedua dengan menggunakan kertas saring Whatman 42, hal ini bertujuan untuk mempercepat proses penyaringan dan memperoleh hasil saringan yang lebih murni. Filtrat yang diperoleh diuapkan pelarutnya dengan rotary evaporator pada suhu $70^{\circ} \mathrm{C}$. Pemilihan suhu didasarkan pada titik didih pelarut (etanol $70 \%$ ) yaitu $78^{\circ} \mathrm{C}$. Jika penentuan suhu lebih dari titik didih dikhawatirkan kandungan senyawa dalam ekstrak akan rusak dan dapat ikut menguap bersama menguapnya pelarut. Dari proses ini diperoleh ekstrak kental daun ginje berwarna hijau kehitaman sebanyak 93,2 g. Dengan demikian, jika dibuat rendemen, konsentrasinya akan menjadi 18,1\%. Hasil ini lebih tinggi jika dibanding dengan ekstrak etanol daun A. Americana yang mempunyai rendemen sebanyak 14,7\% (Khade et al. 2011) dan ekstrak etanol daun Annona muricata 14,86\% (Rachmani dan Suhesti 2012). Dengan demikian, proses ekstraksi dapat dikatakan sudah optimal.

\section{Pencarian eluen terbaik}

Pencarian eluen terbaik dilakukan dengan menggunakan Kromatografi Lapis Tipis (KLT) dengan berbagai eluen, baik eluen tunggal maupun campuran, dari senyawa polar, semipolar, maupun nonpolar. Pencarian eluen terbaik tersebut merupakan tahapan yang penting dilakukan, karena proses ini akan dijadikan dasar dalam tahap selanjutnya, terutama dalam identifikasi kandungan senyawa suatu ekstrak. Eluen terbaik merupakan eluen yang dapat menghasilkan spot dengan kriteria sebagai berikut: warna jelas, jarak teratur (tidak tumpang tindih), dan nilai Rf pada spot berada di antara 0,2-0,8 (Rohman dan Gandjar 2008). Hasil pemisahan spot pada KLT diamati dengan lampu $U_{254} \mathrm{~nm}$ dan $U_{365} \mathrm{~nm}$, serta disemprot dengan serium (IV) sulfat untuk melihat adanya spot yang mungkin belum terlihat pada saat dipapar dengan UV, deteksi ini juga menunjukkan adanya senyawa organik dalam ekstrak. Jika pemisahan spot yang terbentuk pada KLT sudah baik maka eluen sudah dapat digunakan pada tahap berikutnya (tahap partisi dan fraksinasi). Eluen yang dapat memisahkan kandungan senyawa terbaik adalah eluen kloroform 100\% (Gambar 1).

Kloroform dapat memisahkan spot dengan baik dikarenakan sifatnya yang kurang polar. Beberapa eluen yang telah dicoba yang sifatnya lebih polar, memberikan pemisahan spot yang masih tumpang tindih. Hal ini mengindikasikan bahwa senyawa di dalam ekstrak sangat polar, sehingga perlu eluen yang kurang polar untuk dapat memisahkan senyawa dengan baik. Spot yang pertama terikat pada plat KLT adalah paling polar dan semakin ke atas maka kepolaran spot/senyawa semakin berkurang.

Gambar 1 menunjukkan adanya pemisahan spot yang sudah tidak tumpang tindih. Pada deteksi $\mathrm{UV}_{254}$ (Gambar 1A) terlihat ada 1 spot, pada deteksi dengan $U_{365}$ (Gambar 1B) terlihat ada 3 spot, dan deteksi dengan serium (IV) sulfat (Gambar 1C) terlihat ada 3 spot. Spot-spot yang terbentuk antara deteksi satu dengan deteksi yang lain menunjukkan perbedaan profil dan mempunyai nilai Rf yang berbeda. Hal ini menunjukkan adanya beberapa golongan senyawa aktif yang terdapat di dalam ekstrak etanol daun ginje, namun belum dapat diketahui secara spesifik kandungan senyawa kimianya.

\section{Partisi dan uji toksisitas}

Partisi bertujuan untuk memisahkan senyawa polar dan nonpolar. Dalam proses ini dilakukan uji pendahuluan terlebih dahulu untuk menentukan jenis pelarut yang digunakan, sehingga pemisahan senyawa lebih optimal. Hasil partisi dimonitor dengan KLT untuk melihat pemisahan spot antara bagian yang larut dalam pelarut dan bagian yang tidak larut dalam pelarut. Pemisahan yang paling baik adalah dengan pelarut etil asetat, karena antara bagian yang larut dan bagian yang tidak larut, penampakan spot sudah tidak tumpang tindih (Gambar 2). Tidak tumpang tindihnya spot yang terbentuk mengindikasikan bahwa pemisahan antara senyawa polar dan nonpolar sudah optimal. Bagian nonpolar sudah masuk ke dalam bagian yang tidak larut etil asetat dan bagian yang lebih polar masuk ke dalam bagian yang larut dalam etil asetat. Partisi dilakukan dengan melarutkan ekstrak etanol daun ginje sebanyak $90 \mathrm{~g}$ dalam $150 \mathrm{ml}$ etil asetat menggunakan alat sentrifuge dengan kecepatan 2000 rpm selama 10 menit.

Bagian terlarut etil asetat yang diperoleh diuapkan dengan waterbath pada suhu $50^{\circ} \mathrm{C}$ untuk menghilangkan pelarutnya, sehingga diperoleh ekstrak menyerupai pasta. Bagian larut sebanyak $5 \mathrm{~g}$ dan bagian tidak larut sebanyak 17 g. Kedua bagian tersebut selanjutnya diuji toksisitasnya untuk melihat bagian yang lebih aktif.

Uji toksisitas hasil partisi dilakukan dengan metode 
Brine Shrimp Test (BST) terhadap larva udang A. salina berumur 48 jam (Meyer et al. 1982). Keunggulan penggunaan $A$. salina untuk uji BST adalah peka terhadap bahan uji, siklus hidup lebih cepat, mudah dibiakkan, dan harganya relatif murah. Sifat peka A. salina disebabkan oleh kondisi membran kulitnya yang tipis, sehingga memungkinkan terjadinya difusi zat dari lingkungan yang mempengaruhi metabolisme dalam tubuhnya (Rahmawan 2011). Larva udang memberikan kemiripan respons dalam kaitannya dengan sistem yang terjadi pada mamalia, misalnya DNA-dependent RNA polymerase A. salina memiliki tipe yang sama dengan mamalia (Elhardallou 2011). Adapun hasil uji toksisitas bagian larut etil asetat dan bagian tidak larut etil asetat ditunjukkan pada Tabel 2.

Dari Tabel 2, bagian larut etil asetat memberikan persentase kematian yang lebih besar dibanding bagian yang tidak larut etil asetat. Hal ini berarti senyawa aktif yang berperan dalam membunuh larva udang terdapat dalam bagian larut etil asetat, sehingga bagian larut etil asetat diuji lebih lanjut. Mekanisme kematian larva berhubungan dengan adanya suatu senyawa bioaktif dalam menghambat daya makan larva (antifeedant). Cara kerja senyawa bioaktif tersebut bertindak sebagai stomach poisoning atau racun perut. Oleh karena itu, jika senyawasenyawa tersebut masuk ke dalam perut larva maka akan mengganggu pencernaan larva, selain itu senyawa tersebut akan menghambat reseptor perasa pada mulut larva. Hal ini mengakibatkan larva gagal mendapatkan stimulus rasa, sehingga larva tidak dapat mengenali makanannya, akibatnya larva mati kelaparan (Nguyen dan Widodo 1999).

Dari hasil uji toksisitas selanjutnya dicari nilai $\mathrm{LC}_{50}$ untuk menentukan konsentrasi yang akan digunakan untuk uji toksisitas hasil fraksinasi. Setelah dilakukan perhitungan diperoleh nilai $\mathrm{LC}_{50}$ bagian larut etil asetat sebesar 187,23 $\mu \mathrm{g} / \mathrm{mL}$. Dengan demikian, untuk uji selanjutnya cukup digunakan dua konsentrasi di bawah nilai $\mathrm{LC}_{50}$ dan satu konsentrasi di atasnya yaitu 62,5; 125; dan $250 \mu \mathrm{l} / \mathrm{ml}$, karena dengan konsentrasi sebesar 187,23 $\mu \mathrm{g} / \mathrm{mL}$ sudah mampu membunuh 50\% hewan uji.

\section{Fraksinasi dan uji toksisitas}

Fraksinasi dilakukan dengan Kromatografi Lapis Tipis Preparatif (KLTp). Hasilnya dideteksi di bawah lampu $\mathrm{UV}_{254}$ dan sinar tampak.

Pada Gambar 3. terlihat adanya pola-pola tertentu dengan warna yang berbeda. Pola-pola yang terbentuk dan mempunyai warna yang sama dikerok dan dikumpulkan menjadi satu fraksi. Pola-pola ini tidak membentuk garis lurus yang panjang tetapi bergelombang, sehingga sulit ditentukan nilai Rf-nya. Hal ini diduga disebabkan karena permukaan plat silika yang tidak rata atau proses penotolan yang kurang lurus, sehingga pola noda juga tidak lurus. Fraksi yang terbentuk disentrifugasi menggunakan pelarut etil asetat pada kecepatan 2000 rpm selama 10 menit. Hal ini bertujuan untuk memisahkan ekstrak hasil fraksinasi dengan silika gel sebagai pengikat ekstrak. Dari hasil fraksinasi, terbentuk 7 fraksi kemudian dimonitoring dengan KLT untuk melihat pemisahan kandungan senyawanya (Gambar 4).
Hasil tersebut menunjukkan adanya fraksi yang mempunyai profil yang sama, yaitu fraksi 4-5 dan fraksi 67. Fraksi yang mempunyai profil hasil tersebut menunjukkan adanya fraksi yang mempunyai profil yang sama, yaitu fraksi 4-5 dan fraksi 6-7. Fraksi yang mempunyai profil dengan KLT untuk melihat profil kandungan senyawa kimianya (Gambar 5).

Hasil pada Gambar 5 menunjukkan adanya profil yang berbeda antara satu fraksi dengan fraksi yang lainnya setelah penggabungan. Hal ini berarti kandungan senyawa kimia dalam setiap fraksi sudah berbeda, sehingga selanjutnya dilakukan uji toksisitas untuk melihat fraksi yang paling aktif. Fraksi-fraksi ekstrak etanol daun ginje pada bagian yang larut etil asetat hasil penggabungan ditimbang dan diperoleh berat yaitu fraksi I sebanyak 86 mg, fraksi II sebanyak $63 \mathrm{mg}$, fraksi III sebanyak $77 \mathrm{mg}$, fraksi IV sebanyak $86 \mathrm{mg}$, dan fraksi V sebanyak $36 \mathrm{mg}$.

Uji toksisitas hasil fraksinasi menggunakan 3 konsentrasi yaitu 62,5 $\mu \mathrm{g} / \mathrm{mL}, 125 \mu \mathrm{g} / \mathrm{mL}$, dan $250 \mu \mathrm{g} / \mathrm{mL}$. Adapun hasil uji toksisitas hasil fraksinasi disajikan dalam Tabel 3. Dari Tabel 3 dapat diketahui bahwa fraksi yang paling toksik adalah fraksi I, karena mempunyai persentase kematian yang paling besar. Semakin besar konsentrasi maka semakin besar kematian larva udang. Dari hasil tersebut selanjutnya ditentukan nilai $\mathrm{LC}_{50}$ dengan cara mencari linearitas antara log konsentrasi ekstrak dengan persentase kematian larva udang yang telah dikonversi ke dalam bentuk probit. Adapun persamaan linear dan nilai $\mathrm{LC}_{50}$ ditunjukkan pada Tabel 4. Kurva hubungan antara log konsentrasi dan nilai probit kematian larva A. salina ditunjukkan pada Gambar 6.

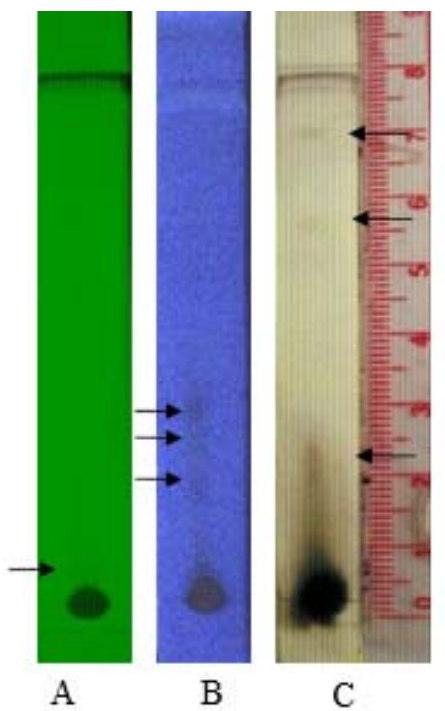

Gambar 1. Kromatogram ekstrak etanol daun ginje dengan deteksi $U_{254}$ (A) dan $U V_{365}$ (B). Deteksi semprot serium (IV) sulfat. Fase diam $=$ silika gel GF254, fase gerak $=$ kloroform $100 \%$, jarak pengembangan $=8 \mathrm{~cm}$, spot ditunjukkan dengan tanda panah 


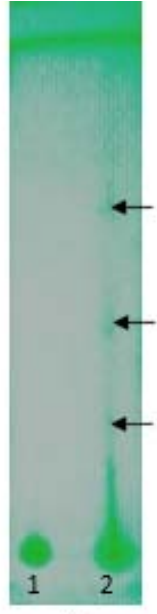

A

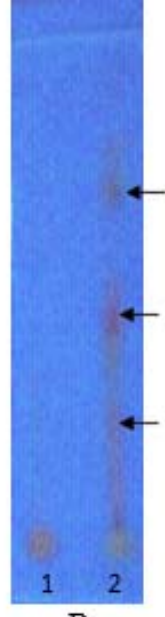

B

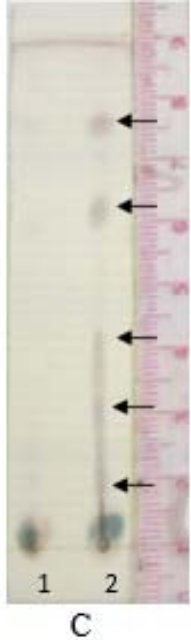

C
Gambar 2. Kromatogram hasil partisi dengan deteksi: (A) $U_{254}$ asetat, (B) $\mathrm{UV}_{365}$, (C) serium (IV) sulfat. 1 = Bagian tidak larut etil asetat, 2 = bagian larut etil asetat, fase diam = silika gel GF254, fase gerak = kloroform $100 \%$, jarak pengembangan $8 \mathrm{~cm}$, spot ditunjukkan dengan tanda panah

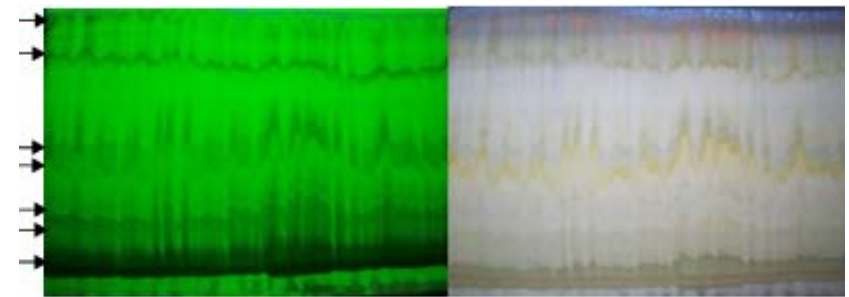

A

B

Gambar 3. Profil hasil fraksinasi dengan KLTp. (A) Deteksi $\mathrm{UV}_{254}$, (B) deteksi Sinar tampak. Fase diam = silika gel GF254, fase gerak $=$ kloroform $100 \%$, jarak pengembangan $=8 \mathrm{~cm}$

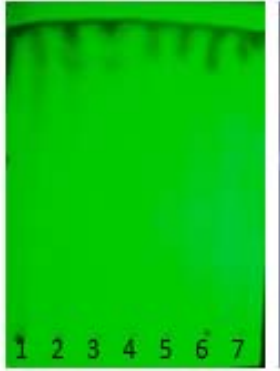

A

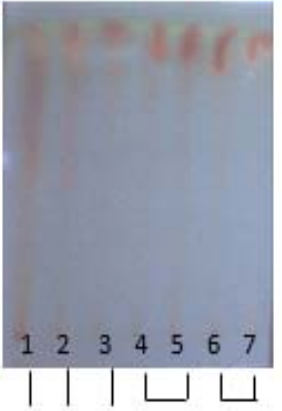

I II III IV $\mathrm{V}$

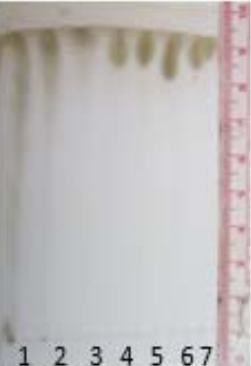

$\mathrm{C}$
Gambar 4. Profil kromatografi lapis tipis tujuh fraksi hasil fraksinasi dengan deteksi (A) $U_{254}$, (B) $U_{365}$, (C) serium (IV) sulfat. Fase diam $=$ silika gel GF254, fase gerak $=$ kloroform $100 \%$, jarak pengembangan $=8 \mathrm{~cm}$

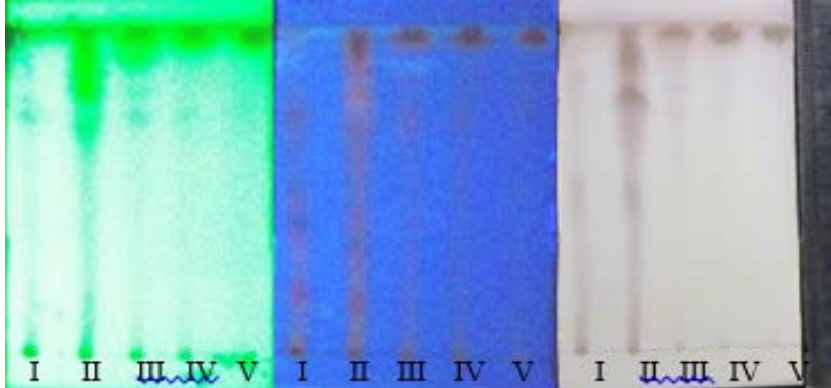

A

B

$\mathrm{C}$

Gambar 5. Profil kromatografi lapis tipis lima fraksi hasil fraksinasi dengan deteksi (A) $U_{254}$, (B) $U_{365}$, (C) serium (IV) sulfat. Fase diam $=$ silika gel GF254, fase gerak = kloroform $100 \%$, jarak pengembangan $=8 \mathrm{~cm}$

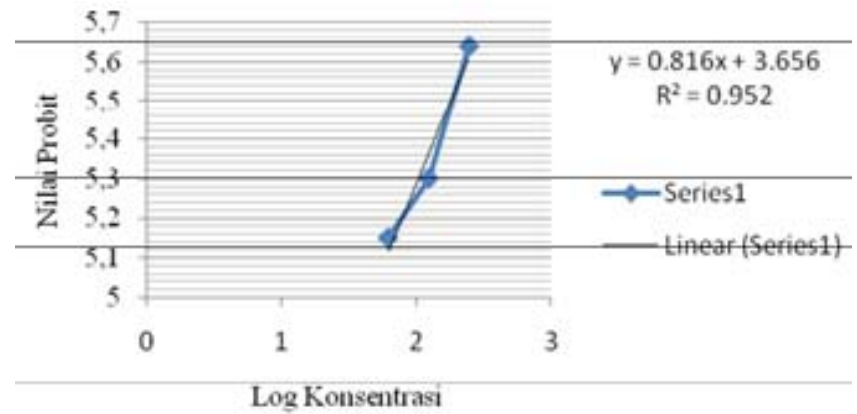

Gambar 6. Kurva regresi linear hasil uji toksisitas fraksi I hasil fraksinasi

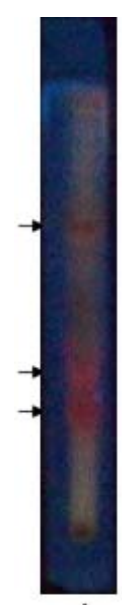

A

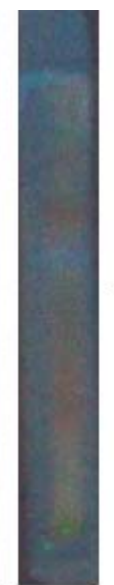

B

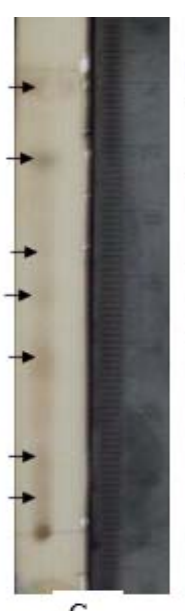

$\mathrm{C}$

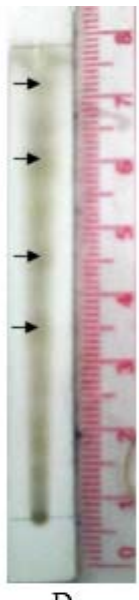

$\mathrm{D}$

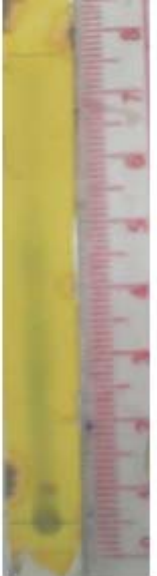

E

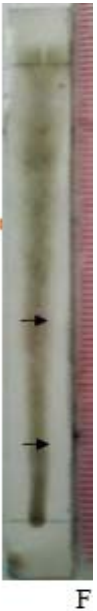

Gambar 7. Profil kandungan kimia fraksi teraktif (fraksi I) ekstrak etanol daun ginje dengan beberapa deteksi penampak bercak. (A) $\mathrm{UV}_{365}$, (B) $\mathrm{UV}_{254}$, (C) serium (IV) sulfat, (D) $\mathrm{FeCl}_{3}$, (E) Dragendorff, (F) Lieberman-Burchard. Fase diam = silika gel $60 \mathrm{GF}$, fase gerak = kloroform: etil asetat (1:3), jarak pengembangan $=7 \mathrm{~cm}$ 
Tabel 1. Jenis pelarut dan komponen aktif yang dilarutkan dalam proses ekstraksi

\begin{tabular}{|c|c|c|c|c|c|}
\hline Air & Etanol & Metanol & Kloroform & Eter & Aseton \\
\hline $\begin{array}{l}\text { Antosianin } \\
\text { Amilum } \\
\text { Tanin } \\
\text { Saponin } \\
\text { Polipeptida } \\
\text { Lektin }\end{array}$ & $\begin{array}{l}\text { Tanin } \\
\text { Polifenol } \\
\text { Poliasetil } \\
\text { Flavonol } \\
\text { Terpenoid } \\
\text { Steroid } \\
\text { Alkaloid }\end{array}$ & $\begin{array}{l}\text { Antosianin } \\
\text { Terpenoid } \\
\text { Saponin } \\
\text { Tanin } \\
\text { Xantoxilin } \\
\text { Totarol } \\
\text { Quassinoid } \\
\text { Lakton } \\
\text { Flavon } \\
\text { Phenone } \\
\text { Polifenol }\end{array}$ & $\begin{array}{l}\text { Terpenoid } \\
\text { Flavonoid }\end{array}$ & $\begin{array}{l}\text { Alkaloid } \\
\text { Terpenoid } \\
\text { Kumarin } \\
\text { Asam lemak }\end{array}$ & $\begin{array}{l}\text { Fenol } \\
\text { Flavonol }\end{array}$ \\
\hline
\end{tabular}

Tabel 5. Hasil uji toksisitas ekstrak etanol daun ginje fraksi I-V dengan metode Brine Shrimp Test (BST)

\begin{tabular}{|c|c|c|c|c|c|c|}
\hline \multirow{2}{*}{$\mathbf{R f}$} & \multicolumn{6}{|c|}{ Penampakan bercak } \\
\hline & $\mathbf{U V}_{254}$ & $\mathbf{U V}_{365}$ & Serum (IV) Sulfat & $\mathrm{FeCl}_{3}$ & Dragendorff & Liebermann-Burchard \\
\hline$\overline{0,07}$ & & & Cokelat tua & & - & Ungu \\
\hline 0,14 & & & Merah bata & & - & \\
\hline 0,29 & Peredaman & Berpendar (merah) & & & - & \\
\hline 0,43 & Peredaman & Berpendar (merah) & Cokelat tua & Hitam & - & \\
\hline 0,47 & & & Merah bata & & - & Ungu \\
\hline 0,57 & & & Cokelat tua & Hitam & - & \\
\hline 0,71 & Peredaman & Berpendar (merah) & & & - & \\
\hline 0,88 & & & Cokelat tua & & - & \\
\hline 0,93 & & & Cokelat tua & & - & \\
\hline
\end{tabular}

Tabel 2. Hasil uji toksisitas bagian larut etil asetat dan bagian tidak larut etil asetat ekstrak etanol daun ginje

\begin{tabular}{lcc}
\hline $\begin{array}{l}\text { Konsentrasi } \\
(\boldsymbol{\mu g} / \mathbf{m L})\end{array}$ & $\begin{array}{c}\text { Rata-rata kematian } \\
(\%) \text { bagian larut }\end{array}$ & $\begin{array}{c}\text { Rata-rata kelarutan (\%) } \\
\text { bagian tidak larut }\end{array}$ \\
\hline 62,5 & 42,00 & 39,33 \\
125 & 46,00 & 43,33 \\
250 & 50,00 & 46,66 \\
500 & 59,33 & 54,66 \\
1000 & 71,33 & 50,00 \\
Rata-rata total & 53,73 & 46,78 \\
\hline
\end{tabular}

Tabel 3. Hasil uji toksisitas ekstrak etanol daun ginje fraksi I-V dengan metode Brine Shrimp Test (BST)

\begin{tabular}{lcc}
\hline Fraksi & Konsentrasi $(\boldsymbol{\mu g} / \mathbf{m L})$ & Rata-rata total \\
\hline Fraksi I & 62,5 & 56 \\
& 125 & 62 \\
Fraksi II & 250 & 74 \\
& 62,5 & 57 \\
& 125 & 59 \\
Fraksi III & 250 & 66 \\
& 62,5 & 53 \\
Fraksi IV & 125 & 55 \\
& 250 & 62 \\
& 62,5 & 34 \\
Fraksi V & 125 & 41 \\
& 250 & 69 \\
& 62,5 & 33 \\
& 125 & 39 \\
\end{tabular}

Tabel 4. Persamaan linear dan nilai $\mathrm{LC}_{50}-24$ jam fraksi I hasil fraksinasi dari bagian larut etil asetat ekstrak etanol daun ginje

\begin{tabular}{lccc}
\hline Log konsentrasi & $\begin{array}{c}\text { Nilai } \\
\text { probit }\end{array}$ & $\begin{array}{c}\text { Persamaan } \\
\text { linear }\end{array}$ & $\begin{array}{c}\mathbf{L C}_{50} \\
(\boldsymbol{\mu g} / \mathbf{m L})\end{array}$ \\
\hline 1,79 & 5,15 & $\mathrm{y}=0,816 \mathrm{x}+3,656$ & \\
2,09 & 5,30 & $\mathrm{R}^{2}=0,952$ & 44,67 \\
2,39 & 5,64 & $\mathrm{y}=0,816 \mathrm{x}+3,656$ & \\
\hline
\end{tabular}

Persamaan linear yang diperoleh digunakan untuk menghitung nilai $\mathrm{LC}_{50}$ dengan cara memasukkan nilai $\mathrm{y}=5$ (nilai probit dari 50\%), sehingga akan diperoleh nilai $\mathrm{x}$ sebagai log konsentrasi kematian larva udang, selanjutnya nilai x diubah menjadi bentuk antilog. Nilai akhir antilog tersebut merupakan nilai $\mathrm{LC}_{50}$-nya. Nilai $\mathrm{LC}_{50}$ yang diperoleh menunjukkan tingkat toksisitas suatu bahan uji. Semakin besar nilai LC $_{50}$ berarti toksisitas suatu bahan uji semakin kecil dan sebaliknya semakin kecil nilai $\mathrm{LC}_{50}$ berarti toksisitas suatu bahan uji semakin besar.

Nilai LC $_{50}$ fraksi I sebesar 44,67 $\mu \mathrm{g} / \mathrm{mL}$. Menurut Meyer et al. (1982) dalam Sukandar et al. (2009), suatu ekstrak dianggap berpotensi sebagai antikanker jika memiliki toksisitas dengan nilai LC $_{50}$ kurang dari 1000 $\mu \mathrm{g} / \mathrm{mL}$. Dengan demikian, hasil tersebut menunjukkan bahwa fraksi I ekstrak etanol daun ginje bersifat toksik dan berpotensi sebagai antikanker. 
Menurut Meyer et al. (1982), ekstrak atau fraksi senyawa yang memiliki harga $\mathrm{LC}_{50}>0-30 \mu \mathrm{g} / \mathrm{mL}$ berpotensi sebagai antikanker, $\mathrm{LC}_{50}>30-200 \mu \mathrm{g} / \mathrm{mL}$ berpotensi sebagai antibakteri, sedangkan $\mathrm{LC}_{50}>200-1000$ $\mu \mathrm{g} / \mathrm{mL}$ berpotensi sebagai pestisida. Beberapa penelitian menunjukkan bahwa tanaman yang diketahui mempunyai aktivitas sebagai antimikroba juga berpotensi sebagai antikanker, karena diduga toksisitasnya juga dapat bekerja pada fase tertentu dari siklus sel kanker (Diastuti dan Suwandri 2009).

Nilai $\mathrm{LC}_{50}$ hasil fraksinasi lebih rendah daripada hasil partisi bagian larut etil asetat. Hal ini menunjukkan bahwa efek toksik hasil fraksinasi lebih besar dari hasil partisi dan menunjukkan juga bahwa fraksi I hasil fraksinasi mempunyai senyawa bioaktif yang lebih spesifik untuk mematikan larva udang, sehingga uji toksisitas dapat berlangsung lebih efektif. Nilai $\mathrm{LC}_{50}(44,67 \mu \mathrm{g} / \mathrm{mL})$ fraksi I hasil fraksinasi bagian larut etil asetat memberikan nilai $\mathrm{LC}_{50}$ yang lebih besar jika dibandingkan dengan nilai $\mathrm{LC}_{50}$ fraksi etil asetat daun pecut kuda $(249,80 \mu \mathrm{l} / \mathrm{ml})$ (Indrayani 2006).

Uji BST menunjukkan bahwa terdapat korelasi positif dengan uji sitotoksik pada beberapa ekstrak tanaman, seperti Ocimum sanctum, Lagerstroemia reginae, Cissampelos pareira, Acaciaconccina, Punica granatum, Aconitum sp., Rosadamascene, Cinchona sp., Bacopa monnieri, dan Symplocos racemosa, dengan tingkat kematian yang signifikan terhadap larva udang (Dahpour et al. 2012). Djajanegara dan Wahyudi (2009) juga membuktikan bahwa hasil uji pendahuluan dari ekstrak kloroform dan etanol daun Annona yang bersifat toksik terhadap larva udang ternyata juga toksik terhadap sel Hela dengan nilai $\mathrm{LC}_{50}$ sebesar 7,695 $\mu \mathrm{l} / \mathrm{ml}$ dan 4,547 $\mu \mathrm{l} / \mathrm{ml}$.

\section{Deteksi kandungan senyawa}

Kandungan senyawa yang terkandung dalam fraksi teraktif ekstrak etanol daun ginje (fraksi I) dianalisis dengan kromatografi lapis tipis (KLT) dan hasilnya dilihat pada $U_{245}$ dan $U_{365}$ serta beberapa pereaksi penampak bercak, yaitu serium (IV) sulfat, Dragendorff, $\mathrm{FeCl}_{3}$, serta Liebermann-Burchard. Pereaksi semprot $\mathrm{FeCl}_{3}$ digunakan untuk mendeteksi senyawa fenol yang akan ditunjukkan dengan bercak berwarna hijau, merah ungu, biru, atau hitam yang kuat (Harborne 1987). Liebermann-Burchard merupakan deteksi semprot golongan senyawa terpenoid, memberikan noda berwarna merah sampai ungu pada sinar visibel (Cannell 1998). Adapun reagen Dragendorff merupakan deteksi untuk senyawa alkaloid yang akan memberikan bercak berwarna jingga sampai cokelat (Wagner dan Bladt 1996). Profil KLT hasil fraksi I hasil fraksinasi ekstrak etanol daun ginje ditunjukkan pada Gambar 7.

Dari Tabel 5, hasil deteksi semprot serium (IV) sulfat memperlihatkan beberapa bercak berwarna cokelat tua (Gambar 7). Warna cokelat yang terbentuk disebabkan karena dalam serium (IV) sulfat terdapat $\mathrm{H}_{2} \mathrm{SO}_{4} 10 \%$ yang bersifat reduktor dapat merusak gugus kromofor dari zat aktif simplisia, sehingga panjang gelombangnya akan bergeser ke arah yang lebih panjang, akibatnya noda menjadi tampak oleh mata setelah pemanasan (Ambarwati
2010). Deteksi ini menunjukkan adanya senyawa organik dalam ekstrak. Pada plat terlihat ada 7 spot, sehingga dapat diartikan pada plat tersebut mengandung banyak senyawa organik. Deteksi $U_{254}$ memperlihatkan adanya peredaman yang ditandai dengan beberapa spot/zona gelap pada latar belakang berflouresensi hijau (Gambar 7). Hasil deteksi dengan sinar $\mathrm{UV}_{254}$ menunjukkan keberadaan suatu senyawa, sedangkan hasil deteksi dengan sinar $\mathrm{UV}_{365}$ (Gambar 7) memperlihatkan bercak terpendar berwarna merah. Hal ini menunjukkan bahwa senyawa tersebut memiliki ikatan rangkap terkonjugasi yang panjang, sehingga dapat berpendar pada penyinaran UV gelombang panjang.

Adapun untuk deteksi senyawa secara spesifik dijelaskan sebagai berikut.

\section{Deteksi Dragendorff}

Deteksi Dragendorff merupakan deteksi senyawa alkaloid. Jika hasilnya positif maka akan muncul bercak berwarna jingga sampai cokelat (Wagner dan Bladt 1996). Pada plat yang telah disemprot dengan deteksi tersebut tidak menunjukkan terbentuknya bercak berwarna jingga atau cokelat, dan hanya terlihat adanya zona berwarna hijau dengan latar belakang kuning maka dapat disimpulkan bahwa fraksi I daun ginje tidak mengandung senyawa golongan alkaloid. Dengan demikian, hipotesis adanya alkaloid dalam fraksi teraktif ekstrak etanol daun ginje tidak terbukti.

\section{Deteksi Liebermann-Burchard}

Deteksi senyawa dengan Liebermann-Burchard menunjukkan adanya senyawa golongan terpenoid yang ditunjukkan dengan adanya noda berwarna merah sampai ungu pada sinar visibel (Cannell 1998). Pada plat setelah disemprot dan dipanaskan dengan oven pada suhu $110^{\circ} \mathrm{C}$ selama 10 menit, terlihat muncul spot berwarna ungu. Namun setelah beberapa saat, warna ungu pada plat sedikit memudar, sehingga spot terlihat kurang jelas. Spot berwarna ungu terlihat pada nilai Rf 0,14 dan 0,47, sehingga dapat disimpulkam bahwa fraksi I ekstrak etanol daun ginje positif mengandung senyawa terpenoid.

\section{Deteksi $\mathrm{FeCl}_{3}$}

Deteksi $\mathrm{FeCl}_{3}$ merupakan deteksi senyawa fenol yang ditunjukkan dengan bercak berwarna hijau, merah ungu, biru, atau hitam yang kuat (Harborne 1987). Pada plat terlihat terbentuk adanya spot berwarna biru tua setelah disemprot dengan $\mathrm{FeCl}_{3}$ dan dipanaskan dengan oven pada suhu $110^{\circ} \mathrm{C}$ selama 10 menit, sehingga fraksi I ekstrak etanol daun ginje positif mengandung senyawa golongan fenolik. Identifikasi kandungan senyawa dalam fraksi I dengan deteksi semprot spesifik menunjukkan adanya golongan senyawa terpenoid dan fenolik, namun masih dimungkinkan terdapat kandungan senyawa lain yang belum teridentifikasi, karena spot yang terbentuk cukup banyak, sehingga diperlukan uji lebih lanjut untuk mengidentifikasi kandungan senyawa kimia dalam fraksi I ekstrak etanol daun ginje. Menurut Diastuti et al. (2008), senyawa flavonoid, terpenoid, dan alkaloid yang terdapat pada fraksi kloroform dari ekstrak etanol kulit batang $R$. 
mucronata, secara sinergis atau individual diduga mampu menghambat cell cycle progression dari sel myeloma. Penelitian oleh Harwoko dan Utami (2011) juga melaporkan bahwa kandungan senyawa kimia dari fraksi aktif (n-heksana:kloroform) dari ekstrak metanol kulit batang $R$. mucronata yang berpotensi sebagai antikanker adalah flavonoid (golongan senyawa fenol) dan terpenoid, serta memiliki aktivitas sitotoksik pada sel kanker myeloma dengan nilai $\mathrm{LC}_{50}$ sebesar $15 \mu \mathrm{g} / \mathrm{mL}$. Zat antikanker yang dihasilkan dari ekstrak tanaman mempunyai mekanisme kerja yang hampir sama dengan obat antikanker golongan antimikotika yang menghambat proses mitosis pada fase metafase. Zat aktif yang terdapat pada ekstrak tanaman obat tersebut akan terikat pada protein mikrotubular, tepatnya tubulin pada GTP, dan akan menghambat kemampuan tubulin untuk berpolimerasi membentuk mikrotubulus, sehingga menghambat pemisahan kromosom dan proliferasi sel (Djajanegara dan Wahyudi 2009).

Poon et al. (2004) melaporkan bahwa senyawa fenolik mempunyai sejumlah aktivitas biologis, termasuk antioksidan. Antioksidan mampu melindungi sel normal karena mampu menghambat oksidasi radikal bebas yang reaktif menjadi radikal bebas yang tidak reaktif dan relatif lebih stabil. Dengan menekan reaksi oksidatif radikal bebas, kerusakan mitokondria sebagai penyedia energi dalam sel dapat dicegah. Antioksidan dapat melindungi disfungsi mitokondria dan gangguan lain yang dapat menyebabkan penyakit.

Aktivitas antitumor dari flavonoid meliputi beberapa mekanisme, yaitu menghambat pertumbuhan sel, menghambat aktivitas protein kinase, menginduksi apoptosis, menghambat sekresi MMP, menghambat invasi sel tumor, menghambat penyebaran sel, dan antiangiogenesis (Kanadaswami et al. 2005). Terpenoid merupakan kelompok senyawa fitokimia terbesar. Saat ini, terpenoid telah dieksplorasi sebagai agen antikanker dalam percobaan medis. Terpenoid secara selektif dapat membunuh sel kanker hati (Thoppil dan Bishayee 2011). Sebagian besar triterpenoid telah dilaporkan dapat menghambat pertumbuhan sel kanker tanpa merusak sel normal (Petronelli et al. 2009). Lu et al. (2010) melaporkan senyawa triterpenoid berupa friedelin dalam ekstrak Caulis bamfusae mampu menghambat pertumbuhan 4 sel kanker, yaitu A375, L929, Hela, and THP-1.

\section{KESIMPULAN}

Fraksi teraktif ekstrak etanol daun ginje dengan metode BST adalah fraksi I yang memiliki efek toksik terhadap larva Artemia salina dengan nilai $\mathrm{LC}_{50}-24$ jam sebesar 44,67 $\mathrm{\mu g} / \mathrm{mL}$ dan kandungan senyawa yang terdapat dalam fraksi teraktif (Fraksi I) ekstrak etanol daun ginje adalah golongan terpenoid dan fenolik.

\section{DAFTAR PUSTAKA}

Ambarwati N. 2010. Uji toksisitas Fraksi Daun Ambre (Geranium radula Cavan.) Terhadap Artemia salina Leach dan Profil Kandungan Kimia Fraksi Teraktif. [Skripsi]. Universitas sebelas Maret, Surakarta.

Aryanti, Ermayanti TM, Mariska I et al. 2005. Isolasi senyawa antikanker dari akar berambut Artemisia cina dan aktivitas inhibisinya terhadap sel kanker mulut rahim. Majalah Farmasi Indonesia 16 (4): 192-196.

Cannell RJP. 1998. How to approach the isolation of a natural product. In: Cannell RJP (ed). Methods in Biotechnology. Volume 4. Natural Products Isolation, Humana, Totowa, NJ.

Cuéllar C, Armando, Okori et al. 2010. Preliminary phytochemical and antimicrobial evaluation of the fresh and dried whole plant extracts from Commelina benghalensis. Rev Colombiana Cienc Anim 2 (1): 104-116.

Dahpour AA, Rahdari P, Sobati Z. 2012. Chemical composition of essential oil, antibacterial activity and brine shrimp lethality of ethanol extracts from Sedum pallidum. J Med Plants Res 6 (16): 31053109.

Diastuti H, Suwandri S. 2009. Fraksinasi dan identifikasi senyawa antikanker ekstrak kulit batang Rhizopora mucronata serta uji toksisitasnya terhadap larva udang (Artemia salina Leach). Molekul 4 (2): 54-61. DOI: 10.20884/1.jm.2009.4.2.63.

Diastuti H, Warsinah, Purwati. 2008. Isolasi senyawa bioaktif pada tanaman Rhizopora mucronata sebagai bahan antikanker. Laporan Penelitian. Lembaga Penelitian UNSOED, Purwokerto.

Djajanegara, Wahyudi. 2009. Pemakaian sel Hela dalam uji sitotoksisitas fraksi kloroform dan etanol ekstrak daun Annona squamosa. Jurnal Ilmu Kefarmasian Indonesia 7 (1): 7-11.

Elhardallou. 2011. Cytotoxicity and biological activity of selected Sudanese medicinal plants. Research Journal of Medicinal Plant 5 (3): 201-229.

Fitria L. 2009. Uji aktivitas antikanker secara in vitro dengan sel murine P-388 senyawa flavonoid dari fraksi etil asetat akar tumbuhan tunjuk langit (Helmynthostachis Zeylanica (Linn) Hook). Jurnal Penelitian Sains 12 (1).

Harborne JB. 1987. Metode fitokimia: Penuntun cara modern menganalisis tumbuhan. (Diterjemahkan oleh: Padmawinata K, Soediro I). ITB Press, Bandung.

Harwoko, Utami ED. 2011. Aktivitas Sitotoksik Fraksi n-Heksana: Kloroform dari Ekstrak Metanol Kulit Batang Mangrove (Rhizopora mucronata) pada Sel Kanker Myeloma. Jurusan Farmasi, Universitas Jenderal Soedirman, Purwokerto.

Hasan MM, Saha AK, Khan SA et al. 2011. Studies on the antidiarrhoeal, antimicrobial and cytotoxic activities of ethanol-extracted leaves of yellow oleander (Thevetia peruviana). Open Veterinary Journal 1: 2831.

Indrayani L, Soetjipto H, Sihasale L. 2006. Skrining fitokimia dan uji toksisitas ekstrak daun pecutkuda (Stachytarpheta jamaicensis L. Vahl) terhadap larva udang Artemia salina Leach. Berk Penel Hayati 12: 57-61.

Kanadaswami C, Lee LT, Lee PPH. 2005. The antitumor activities of flavonoids. In Vivo 19: 895-910.

Khade KV, Dubey H, Tenpe CR et al. 2011. Anticancer activity of the ethanolic extracts of Agave americana leaves. Pharmacologyonline 2: 53-68.

Kumar A, Singh S, Mahour K et al. 2011. Phytochemical analysis of some indigenous plants potent against ectoparasite. Asian J Exp Biol Sci 2 (3): 506-509.

Langford SD, Boor PJ. 1996. Oleander toxicity: An examination of human and animal toxic exposures. Toxicology 109: 1-13.

Lu B, Liu L, Zhen X et al. 2010. Anti-tumor activity of triterpenoid-rich extract from bamboo shavings (Caulis bamfusae in Taeniam). Afr $\mathrm{J}$ Biotechnol 9 (38): 6430-6436.

Maridass M. 2008. Evaluation of brine shrimp lethality of Cinnamomum species. Ethnobotanical Leaflets 12: 772-775.

Meyer BN, Ferrigni NR, Putnam JE et al. 1982. Brine shrimp: A convenient general bioassay for active plant constituents. Planta Med 45: 31-34.

Mollah JU, Islam W. 2007. Toxicity of Thevetia peruviana (Pers) Schum. extract to adults of Callosobruchus maculatus F. (Coleoptera: Bruchidae). J Agric Rural Dev 5: 105-109.

Nguyen HH, Widodo. 1999. S. momordica L. In: De Padua LSN, Bunyapraphatsana, Lemmens RHMJ (eds). Medicinal and Poisinous 
Plant Research of South-East Asia 12. Pudoc Scientific Publisher, Wageningen, The Netherland.

Petronelli A, Pannitteri G, Testa U. 2009. Triterpenoids as new promising anticancer drugs. Anticancer Drugs (20): 880-892.

Poon HF, Calabrese V, Butterfield DA. 2004. Free radicals and brain aging. Clinical Geriatric Medical (20): 329-359.

Prashant T, Kumar B, Kaur M et al. 2011. Phytochemical screening and extraction: A review. Int Pharm Sci 1 (1): 98-106.

Rachmani EPN, Suhesti TS. 2012. The breast of anticancer from leaf extract of Annona muricata againts cell line in T47D. International Journal of Applied Science and Technology 2 (1): 157-164.

Rahmawan AJ. 2011. Bioaktivitas Ekstrak Etanol Suren Beureum (Toona Sinensis Roemor) Terhadap Larva Udang Artemia salina Leach. [Skripsi]. Departemen Hasil Hutan, Fakultas Kehutanan, Institut Pertanian Bogor, Bogor.

Roberts DM, Wijayaweera D, Eddleston M. 2005. Yellow oleander poisoning. Anuradhapura Medical Journal 4: 12-17.

Rohman A, Gandjar IG. 2008. Kimia farmasi analisis. Pustaka Pelajar, Yogyakarta.

Sari LK. 2006. Pemanfaatan obat tradisional dengan pertimbangan manfaat dan keamanannya. Majalah Ilmu Kefarmasian 3: 1-7.
Setyowati EP, Jenie UA, Sudarsono et al. 2007. Isolasi senyawa sitotoksik spons Kaliapsis. Majalah Farmasi Indonesia 18 (4): 183-189.

Sriwahyuni I. 2010. Uji Fitokimia Ekstrak Tanaman Anting-anting (Acaypha indica Linn) dengan Variasi Pelarut dan Uji Toksisitas Menggunakan Brine Shrimp (Artemia salina Leach). [Skripsi]. UIN Maulana Malik Ibrahim, Malang.

Sukandar D, Hermanto D, Lestari E. 2009. Uji potensi aktivitas antikanker ekstrak daun pandan wangi (Pandanus amaryllifolius Roxb) dengan metode Brine Shrimp Lethality Test (BSLT). JKTI 11 (1): 32-38.

Sukardiman, Rahman A, Pratiwi NF. 2004. Uji praskrining aktivitas antikanker ekstrak eter dan ekstrak metanol Marchantia cf. planiloba Steph. dengan metode uji kematian larva udang dan profil densitometry ekstrak aktif. Majalah Farmasi Airlangga 4 (3).

Thomas ANS. 1986. Tanaman obat tradisional. Kanisius, Yogyakarta.

Thoppil RJ, Bishayee A. 2011. Terpenoids as potential chemopreventive and therapeutic agents in liver cancer. World J Hepatol 3 (9): 228249.

Wagner H, Bladt S. 1996. Plant drug analysis a thin layer chromatography atlas, $2^{\text {nd }}$ Edition. Springer-Verlag, Berlin, Hiedelberg, New York. 